3. Hughes, R. \& Dunkin, S. 1984. J. Exp. Mar. Biol. Ecol., 77: 45-68.

4. Palmer, A. 1984. Oecologia, 62: 162-192.

5. Burrows, M. \& Hughes, R. N. 1989. J. Moll. St., 55: 286-296.

6. Burrows, M. \& Hughes, R. N. 1990. J. Anim. Ecol., 59: 723-742.

7. SELIN, N. 1985. Biologiya morya, N 2: 73-76 (In Russian).
8. Hughes, R. \& DREWETt, S. 1985. J. Moll. Stud., 51: 73-77.

9. BuYANOVSKY, A.I. Zool. Zh. (In Russian, in press).

10. Hughes, R.N. \& Burrows, M.T. 1991. Anim. Behav., 42: 47-55.

11. BuYANOVSKY, A.I. Zool. Zh. (In Russian, in press).

12. WICKENS, P. \& GRIFFTHS, C.L. 1985. Veliger, 27: 366-374.

\title{
The effect of lichen diet on growth rate in the rock-dwelling land snails Chondring clienta (Westerlund) and Balea perversa (Linnaeus)
}

\author{
Anette Baur ${ }^{1}$, Bruno Baur ${ }^{1}$ and Lars Fröberg ${ }^{2}$ \\ ${ }^{1}$ Zoological Institute, Basel University, Rheinsprung 9, CH-4051 Basel, Switzerland \\ ${ }^{2}$ Department of Systematic Botany, Lund University, Ostra Vallgatan 18-20, S-223 61 Lund, Sweden
}

A previous account of the damage caused by snail grazing to various species of calcicolous lichens covering rock-faces in the Baltic island of Öland (Sweden) indicated species-specific food preferences. ${ }^{1}$ In the limestone grassland Great Alvar on Öland, 108 species of calcicolous lichens have been recorded. ${ }^{2,3}$ These lichens may provide a diverse food supply to herbivores. Among potential lichen feeders, the land snails Chondrina clienta (Westerlund, 1883) and Balea perversa (L., 1758) are well adapted to rocky habitats; they are very resistant to drought and their specialized radulae enable them to graze on epi- and endolithic lichens as well as on free-living alga from rock-faces. ${ }^{4-6}$ Both snail species co-occur in stone walls made of flat pieces of limestone in the Great Alvar. ${ }^{7,8}$ It has been experimentally demonstrated that both species are involved in intra- and interspecific competition and that food is most likely the limiting resource. $9-11$

Lichen species differ in surface toughness, energy content and composition of secondary metabolites, and thus in food quality. Secondary metabolites can act as antiherbivore agents. ${ }^{12}$ Food quality, in turn, influences life-history characters in animals. ${ }^{13}$ Measurements of juvenile growth rate should provide reliable estimates of net food quality. Faster growth rates are likely to reflect more favourable cost-benefit ratios of different food types to an animal. Excluding any costs of food search, a herbivorous snail still has to expend time and/or energy overcoming the lichen's chemical defences, ingesting the lichen, replacing lost feeding structures (e.g. teeth of radula), and assimilating the resources provided by the lichen. Thus, when attempting to resolve specific cost-benefit functions on the common currency basis of total energy, a simple definition of lichen nutritive quality in terms of caloric content is, probably, inappropriate. ${ }^{14}$ In this note we provide experimental evidence that two species of calcicolous lichens and free-living cyanobacteria affect differentially the juvenile growth rates of $C$. clienta and B. perversa.
Juvenile individuals of $C$. clienta and $B$. perversa and pieces of limestone (measuring approximately $5 \mathrm{~cm}$ in diameter) covered with the lichens Clauzadea immersa (=Lecidea immersa) or Tephromela atra (=Lecanora atra) or with free-living cyanobacteria were collected in the grassland Great Alvar on the Baltic island of Öland $\left(56^{\circ} 33^{\prime} \mathrm{N}, 16^{\circ} 36^{\prime} \mathrm{E}\right)$ in October 1990. To examine the net food quality of both lichen species and cyanobacteria to their common snail grazers, groups of ten juveniles of either $C$. clienta or $B$. perversa were raised on each diet in transparent plastic dishes $(6.5 \mathrm{~cm}$ in diameter, $2 \mathrm{~cm}$ in height) for 30 days (four replicates for each snail species and diet). To provide a defined amount of food, a 'feeding area' (approximately $4 \mathrm{~cm}^{2}$ ) covered uniformly with a single lichen species or cyanobacteria was offered to the test animals, whereas the remaining surface of the piece of limestone was covered with tape. The shell height of snails was measured to the nearest $1 / 12 \mathrm{~mm}$ using a binocular microscope with a stage micrometer. The initial shell height of $C$. clienta in all groups averaged $2.66 \mathrm{~mm}$ (mean of within-group SD $=0.01$ ) and that of $B$. perversa $5.51 \mathrm{~mm}(0.01)$. In general, snails are active only during periods of high air humidity, during which they graze lichens. ${ }^{15}$ To stimulate periodic snail activity, the containers were moistened and kept wet for 12 hours and subsequently allowed to dry for 36 hours. For details of snail maintenance see Baur \& Baur. ${ }^{10}$ After 30 days, the shell height of each snail was remeasured. For individuals of both species the wet weight (mass) was calculated using speciesspecific equations of the wet weight-shell height relationship given in Baur \& Baur. ${ }^{10}$ Growth rate was defined as the increase in wet weight during the experimental period of 30 days. Percentages of wet weight increase (i.e. the relative growth rate) were used for interspecific comparisons. All statistical tests were based on dish means.

The growth rates of juvenile $C$. clienta and $B$. perversa raised on different diets are given in Table 1. Chondrina clienta grew best when fed on cyano- 
bacteria or Clauzadea immersa (the growth rates of snails kept on either diet did not differ; MannWhitney U-test, $P=0.88$ ). The growth rate of juvenile C. clienta raised on Tephromela atra was significantly lower than those of conspecifics kept on the former two diets (Mann-Whitney U-test, in both comparisons, $\mathrm{P}<0.05$ ). By contrast, $B$. perversa grew best when fed on $T$. atra (Mann-Whitney U-test, in both comparisons, $\mathrm{P}<0.05$ ). Juveniles of $B$. perversa kept either on $C$. immersa or on cyanobacteria did not differ in growth rate (Mann-Whitney U-test, $P=$ $0.15)$.

An interspecific comparison of relative growth rates (percentage weight increase) revealed that $C$. clienta grew faster on a $C$. immersa diet than did $B$. perversa (Mann-Whitney U-test, $P<0.05$ ). On the other hand, $B$. perversa grew faster when raised on $T$. atra than did $C$. clienta (Mann-Whitney U-test, $\mathrm{P}<$ 0.05 ). This suggests that the same lichen species may be of differential net food quality to different snail species.

The differences in juvenile growth rates between $C$. clienta and $B$. perversa fed on $T$. atra coincide with the results of food preference tests. ${ }^{1}$ In choice tests, $C$. clienta refused to eat $T$. atra, whereas $B$. perversa fed readily on it.

Segregation by diet is one of the most important means by which ecologically similar species partition resources. Niche segregation has been demonstrated in various animal taxa including insects, fish, reptiles, and birds. ${ }^{16,17}$ In the present study, we measured the growth rate of juvenile snails fed on free-living cyanobacteria and on two out of 108 lichen species present in the investigation area. The few lichen species tested do not allow us to draw any general ecological conclusions concerning the food niches of the snails. Nevertheless, our experiment revealed differential growth rates among snail species raised on the same lichen species. This finding could reflect an evolved niche divergence as a result of previous avoidance of competition or alternatively, the observed pattern could result from independent, species-specific adaptations to different diets.

Several calcicolous lichen species contain secondary metabolites, which can act as chemical defence against herbivores. ${ }^{12}$ Tephromela atra, which has been observed in association with mites and collembola, ${ }^{18,19}$ contains both atranorin and $\alpha$-collatolic acid. Our results suggest that $B$. perversa is better than $C$. clienta in dealing with these substances or, alternatively, $B$. perversa can utilize some kind of nutrition from this lichen species that $C$. clienta cannot. Further studies are needed to understand the differential nutritional value or chemical activity of the same lichen species to the snails $C$. clienta and $B$. perversa.

We thank N. Rank and B. Speiser for comments on the manuscript. Financial support was received from the Swiss Academy of Sciences (travel grant to AB) and the Swiss National Science Foundation (grant No. 31-26258.89 to BB) 


\section{REFERENCES}

1. Fróberg, L., Baur, A. \& Baur, B. 1992. (Lichenologist, in press).

2. FRÓBERG, L. 1988. Acta phytogeogr. suec., 76: 4752.

3. FROBERG, L. 1989. The calcicolous lichens on the Great Alvar of Oland, Sweden. PhD. Thesis, University of Lund.

4. SCHMID, G. 1929. Biol. Zentralbl., 49: 28-35.

5. GitTEnBERGER, E. 1973. Zool. Verhand. Leiden, 127: 1-267.

6. Breure, A.S.H. \& GTTENBERGER, E. 1982. Neth. J. Zool., 32: 307-312.

7. BAUR, B. 1987. Basteria, 51: 129-133.

8. BAur, B. 1988. Biol. J. Linn. Soc., 35: 247-259.

9. BAUR, A. 1990. Oikos, 57: 333-337.

10. BAUR, B. \& BAUR, A. 1990. J. Anim. Ecol., 59: 301-315.

11. Baur, A. \& Baur, B. 1991. J. Moll. Stud., 57: 331-336.

12. LAWREY, J.D. 1984. Biology of lichenized fungi. Praeger, New York.
13. Hald, S.J. \& TOdd, C.D. 1986. J. Moll. Stud., 52: 193-205.

14. Palmer, A.R. 1983. J. Exp. Mar. Biol. Ecol., 73: 95-124.

15. NeuCKEL, W. 1981. Zu Aktivitātsregelung und Wasserhaushalt von Chondrina avenacea (Bruguiere 1792), einer Felsen bewohnenden Landlungenschnecke. PhD. Thesis, University of Basel.

16. Strong, D.R. JR, Simberloff, D., Abele, L.G. \& Thistle, A.B. (eds.) 1984. Ecological communities, conceptual issues and the evidence. Princeton: Princeton University Press.

17. Begon, M., Harper, J.L. \& Townsend, C.R. 1990. Ecology: Individuals, populations and communities. Blackwell Scientific Publications, Oxford.

18. Gelstrup, P. \& Søchting, U. 1984. Acarology, 1: 528-532.

19. СøChting, U. \& Gelstrup, P. 1985. Holarct. Ecol., 8: 66-75. 